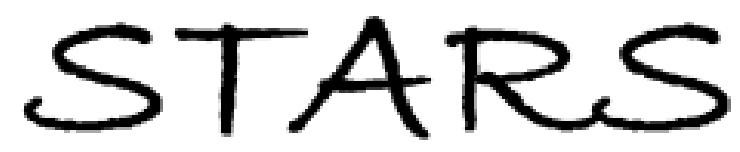

University of Central Florida

STARS

$1-1-2010$

\title{
Interorganizational Network Coordination under Stress Caused by Repeated Threats of Disasters
}

\author{
Naim Kapucu \\ University of Central Florida \\ Thomas Bryer \\ University of Central Florida \\ Vener Garayev \\ University of Central Florida \\ Tolga Arslan
}

Find similar works at: https://stars.library.ucf.edu/facultybib2010

University of Central Florida Libraries http://library.ucf.edu

This Article is brought to you for free and open access by the Faculty Bibliography at STARS. It has been accepted for inclusion in Faculty Bibliography 2010 s by an authorized administrator of STARS. For more information, please contactSTARS@ucf.edu.

\section{Recommended Citation}

Kapucu, Naim; Bryer, Thomas; Garayev, Vener; and Arslan, Tolga, "Interorganizational Network Coordination under Stress Caused by Repeated Threats of Disasters" (2010). Faculty Bibliography 2010 s. 333.

https://stars.library.ucf.edu/facultybib2010/333

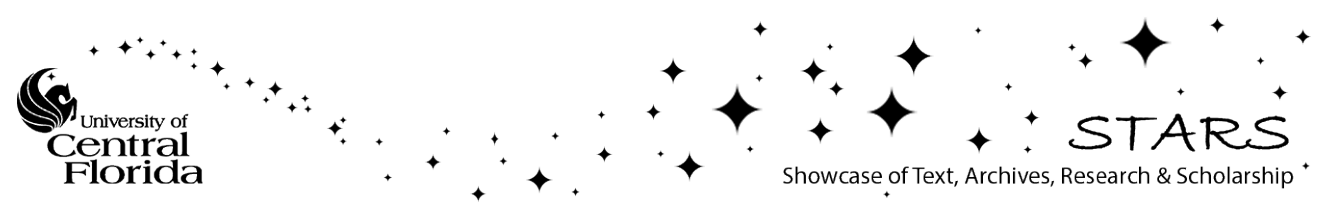




\title{
Journal of Homeland Security and Emergency Management
}

Volume 7, Issue 1

2010

Article 45

\section{Interorganizational Network Coordination under Stress Caused by Repeated Threats of Disasters}

\author{
Naim Kapucu, University of Central Florida \\ Thomas Bryer, University of Central Florida \\ Vener Garayev, University of Central Florida \\ Tolga Arslan, University of Georgia
}

Recommended Citation:

Kapucu, Naim; Bryer, Thomas; Garayev, Vener; and Arslan, Tolga (2010) "Interorganizational

Network Coordination under Stress Caused by Repeated Threats of Disasters," Journal of

Homeland Security and Emergency Management: Vol. 7: Iss. 1, Article 45.

DOI: $10.2202 / 1547-7355.1629$ 


\title{
Interorganizational Network Coordination under Stress Caused by Repeated Threats of Disasters
}

\author{
Naim Kapucu, Thomas Bryer, Vener Garayev, and Tolga Arslan
}

\begin{abstract}
The study addresses interorganizational learning and coordination as well as their impact on collaborative capacity building in disaster environments. Community coordination requires communication and planning to take necessary precautions in the face of severe threats of disasters. The historically unique case of the four Florida hurricanes of 2004 is used to assess coordinated response under conditions of repeated threats of hurricanes. The repeated threat scenario suggests that emergency managers must vigilantly work to keep the partnering public, private, and nonprofit agencies and citizens informed and apprised of the seriousness of the situation. The research examines four hurricane response operations drawing on content analyses of news and situation reports. Content analysis provides interorganizational interactions that are subject to network analysis revealing information about: (1) how critical actors interacted and coordinated, (2) sub-groups under each network, and (3) each network as a system. Using network analysis in analyzing disaster response systems is a new way of exploring the issues from another perspective and through a new methodology. The article showcases the potential use of network analysis in both organizational and emergency management research.
\end{abstract}

KEYWORDS: hurricanes, repeated disaster threats, organizational learning, disaster management, collaborative capacity 
We expect that people will learn from disasters. We also expect 'metaphorically' that organizations will learn as well. However, organizations do not have the cognitive capacity to learn. Organizations learn through their members (i.e. leaders, managers) (Comfort 1999, 1996; Sabatier 1987). On the other hand, organizations can also be utilized to eliminate the limitations of human learning (Jones 2001; Kayes 2004, 2002). In order for organizational learning to occur, organizations need to interact, to share information and resources (Argote 1999; Ostrom 1998; Scott and Davis 2007). However, organizational learning is not simply the sum of individual learning. Organizational learning occurs as organizations adapt existing skills to new and emerging problems (Birkland 2006). Organizations learn when individual experiences and learning are embedded in organizational routines and practices which contribute to organizational effectiveness (Kim 1998). The article uses learning from previous hurricanes in coordinating resources in response to repeated disasters.

Social scientists have studied the resilience of organizations under stress (Tierney 2000) and the collapse of sense-making in organizations under threat (Weick 2001). The scope and complexity of response operations require a flexible learning approach that engages each of the emergency management agencies and requires adjustments in their performance (Carley and Harrald 1997; Kapucu 2009; Orton and Weick 1990; Weick and Sutliffe 2001). When a disaster occurs, we hope that organizations learn from one another and perform at levels that lie beyond the capacity of the individual organizations acting alone. As emergency response and management increasingly rely on inter-organizational response to disasters (Corbacioglu and Kapucu 2006; Kapucu 2006; Moynihan 2005, 2006), research on how organizations learn in the face of repeated disasters takes on heightened importance. Disasters produce unique combinations of choices, actions, and reasoning that can not be predicted. This perspective better represents the complexity of disaster situations and the problematic nature of post-event evaluations.

Building collaborative capacity and coordinating community resources in response to incidents is a major problem for public leaders trying to ensure effective public response to repeated threats (Drabek 1987, 2003; Fitzpatrick 1999; Waugh 2006). Repeated threats and threat warnings from disease, terrorism, and hurricanes can create community numbness causing underestimation and under-preparedness. This can result in increased public exposure to imminent dangers, may cause additional loss of property and life, and lead to slower recovery (Bazerman and Watkins 2004; Burby 1998; Williams and Olaniran 1998). In 2004, the state of Florida was struck by four consecutive major hurricanes within a period of six weeks. Hurricane Charley made landfall on August 13, Hurricane Frances on September 5, Hurricane Ivan on September 16, 
and Hurricane Jeanne on September 25. Combined, the hurricanes killed 117 people and caused more than an estimated $\$ 45$ billion in damages (FDEM 2004). State officials estimated that more than 9.5 million people evacuated Florida during the historic hurricane season - 1.9 million during Hurricane Charley, 2.8 million during Francis, more than 2 million during Hurricane Ivan, and nearly 2 million during Hurricane Jeanne (FEMA 2005). Nevertheless, the repeated strikes provided a once-in-a-lifetime opportunity to study the effect of multiple, consecutive incidents on inter-organizational operations (see Figure 1 for path of the hurricanes and the impacted regions). They also provided an opportunity to study government agency response from immediate past emergency management experiences and to explore their effectiveness in disaster response operations (Birkland 1997, 2006; Kayes 2002, Kettl 2004; Khademian 2004). Effectiveness in this study is defined as 'collaborative capacity building' in response to disasters, and emphasize the importance of information sharing and interaction among responding agencies (Weber and Khademian 2008).

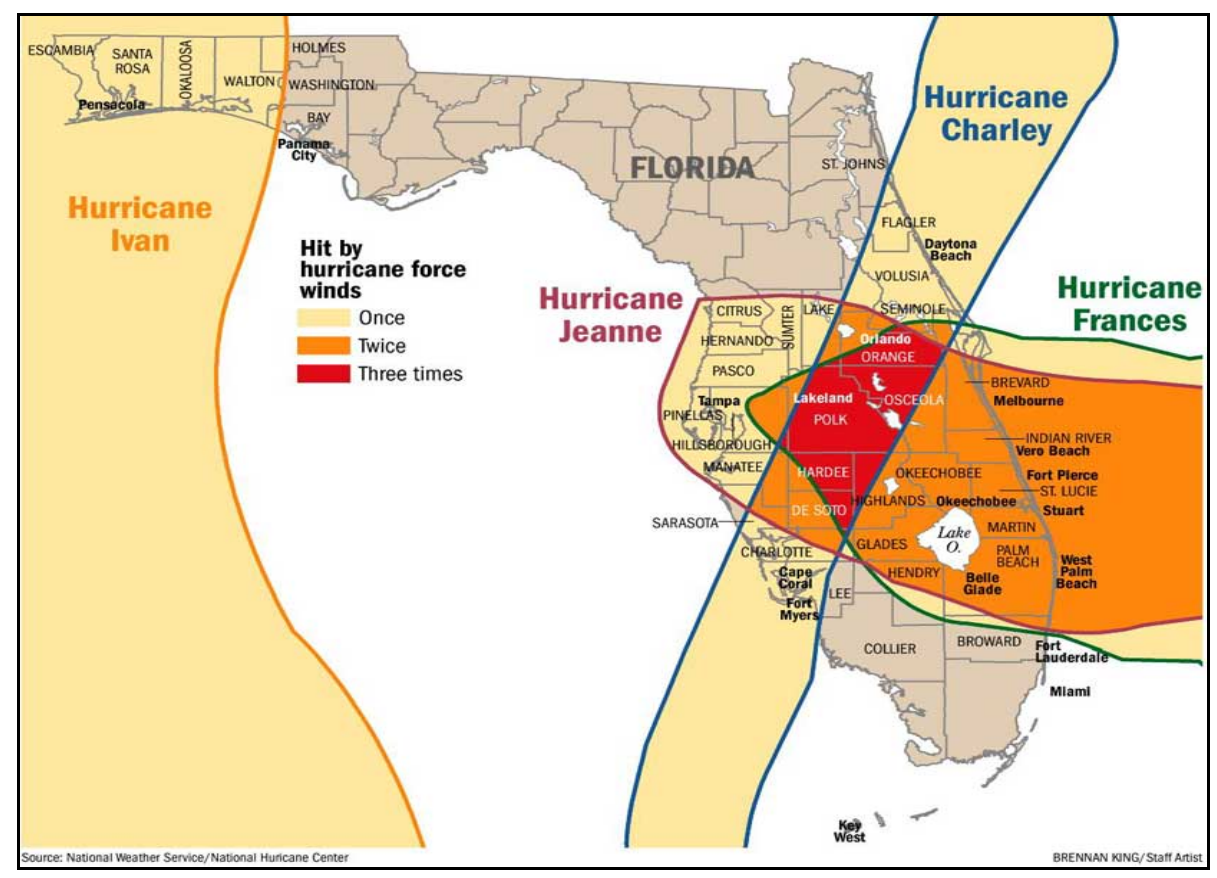

Figure 1: The Path of the Four Hurricanes in 2004 in Florida

The historically unique case of the four hurricanes of 2004 in Florida is used to assess inter-organizational operations under conditions of repeated disasters. The research examines government agencies' (local and state) role in building collaborative capacity in response to repeated disasters. The research uses data from content analysis of government documents, newspaper reports and 
interviews. This article contributes to emergency management literature and specifically to inter-organizational operations under stress (Dynes and Tierney 1994; Fischer 1998; Flin, Salas, Strub, and Martin 1997; McLoughlin 1985; Mileti 1999; Pellig 2003; Seeger et al. 2003; Tierney, Lindell, and Perry 2001; Waugh 2000). The inter-organizational strategies identified by public managers during the response to hurricanes can also be applicable to the response to other natural and manmade disasters. Network analysis has a potential to contribute to emergency management research as a theoretical lens and an analytical tool (Durland and Fredericks 2006; Kilduff and Tsai 2007; Mandell and Keast 2007; Provan, Veazie, Staten, and Teufel-Shone 2005).

\section{Theoretical Background}

In the field of public administration, there have been significant theoretical discussions on policy networks, collaborative decision making, and network management (Agranoff and McGuire 2003; Berry, Brower, Choi, Goa, Jang, Kwon, and Word 2004; Gray 1989; Nohria and Eccies 1992; Kickert Eric-Hans Klijn, and Koopanjan 1997). Simon (1947, 1996) discusses how government agencies learn from experience and adapt to the changes in the environment. Cyert and March (1963) conceptualize organizations as "adaptive institutions" that respond to environmental changes by changing decision protocols and problem-solving activities.

Networks facilitate interaction, decision-making, cooperation, and organizational learning. Scholars also state that collaboration can result in interorganizational learning (Blatner, Carroll, Daniels, and Walker 2001; Daniels and Walker 2001). The scope and complexity of response operations requires a flexible approach that engages each of the emergency management agencies so they adjust their performance in accordance with changing conditions and demands on other responding organizations (Kilduff and Tsai 2007; Powell 1990; Thompson 2007; Weick and Roberts 1993; Weick and Sutliffe 2001). Organizations and individuals learn through processes of knowledge acquisition, information dissemination, information interpretation, and organizational memory (Axelrod 1997). Disasters may instigate organizational learning.

New knowledge, understanding, and insights, for example, often arise as a consequence of crisis. Crisis creates a time of intense self-reflection and debriefing as members actively seek to understand what went wrong and why. Information is rapidly distributed during a crisis because of heightened and unified attention. Because crisis creates high uncertainty by disrupting established expectations and prompts the search for information. (Seeger et al. 2003: 18) 
Other research suggests that organizations will tend to not learn during disaster unless there is a concerted push to do so. Organizations may become rigid and defensive, particularly if there is criticism of the organization's operations during disaster management (Birkland 2006; Janis 1989).

Busenberg (2001) defines learning as "a process in which individuals apply new information and ideas to policy decisions" (p. 22). Morgan (1997) describes the organization in one image as a brain, using 'cybernetic' theory and 'holographic' concepts and characterizes the organization in a "state of flux as an encoded logic of change," with a tendency for organizations to be self-producing systems and random variation as a source of change. Entropy and the tendency to run down are true for relatively closed systems. The network and complex adaptive systems theories suggest that there will be new emerging forms that will shape society in new and productive ways (Buchanan 2002; Holland 1998; Kiel 1994; Kilduff and Tsai 2007; Mackenzie 1991; Wagenaar 2007).

Comfort (1996) notes the inappropriateness of simple, linear models to capture the conditions in disaster environments in which "there are too many agents involved in performing too many different functions simultaneously under radically altered conditions to attribute direct, linear causality to any one agent or condition" (p. 3). This perspective better represents the complexity of disaster situations and the problematic nature of post-event evaluations. Weick (1993, 1995) states that information is the common raw material that all organizations and individuals process. Through communication, participants collectively interpret and make sense of information in their environment. Ostrom (1998) explores the concept of collective action and learning among organizations in dynamic environments. Using the concept of self-organization and learning by a single actor as an initial point of action, Ostrom observes that these processes of learning and adaptation extend to a set of interacting organizations and agencies. These interactions are critical to understanding the dynamics of complex systems (Buchanan 2002), such as those characteristic of disaster environments.

Networks and complex adaptive systems can lead to resilient communities, which have the ability to mitigate hazards, contain the effects of disasters when they occur, and carry out activities in ways that minimize social disruption and mitigate the effects of future disaster events. Resilient communities are characterized by reduced failure, measured in terms of lives lost, damage, and negative social and economic impacts, and reduced time to recovery - that is, more rapid restoration of the social systems and institutions to their normal, predisaster levels of functioning (Wildawsky 1971). The Resilience Multidisciplinary Center for Earthquake Engineering Research (MCEER 2002) has identified four general properties that can be applied to all systems and to the elements that comprise systems: 
- robustness (ability to withstand the forces generated by a hazard agent without loss or significant deterioration of function;

- resourcefulness (capacity to apply material, informational, and human resources to remedy disruptions when they occur);

- redundancy (the extent to which elements, systems, or other units of analysis exist that are capable of satisfying the performance requirements of a social unit in the event of loss or disruption threatening functionality);

- and, rapidity (the ability to contain loses and restore system or other units in a timely manner). (MCEER, 2002)

Public organizations can contribute to resilience in a society by collaborating with nonprofit and private organizations in response to and recover from disasters.

Organizational learning requires human connections (Argote 1999; Nonaka 1994). Researchers have examined the relational components of knowledge transfer (Levin and Cross 2004) and the conditions under which knowledge is transferred to assist organizations in becoming learning organizations (Argyris and Schon 1978, 1996; Garvin 1993; Goh 1998). Effective organizational learning requires prior experience and intense effort among emergency response agencies (Cohen, and Levinthal 1990; Kim 1998; Rochet, Karamidas, and Bout 2008). The study assumes that a response system composed of multiple agencies and jurisdictions will be able to learn and adapt more appropriately to the repeated threats in a given region than uncoordinated efforts by agencies acting independently to meet the same challenges (Comfort 1999; Comfort and Kapucu 2006; Kauffman 1993; McEntire 2002; Schneider 1995).

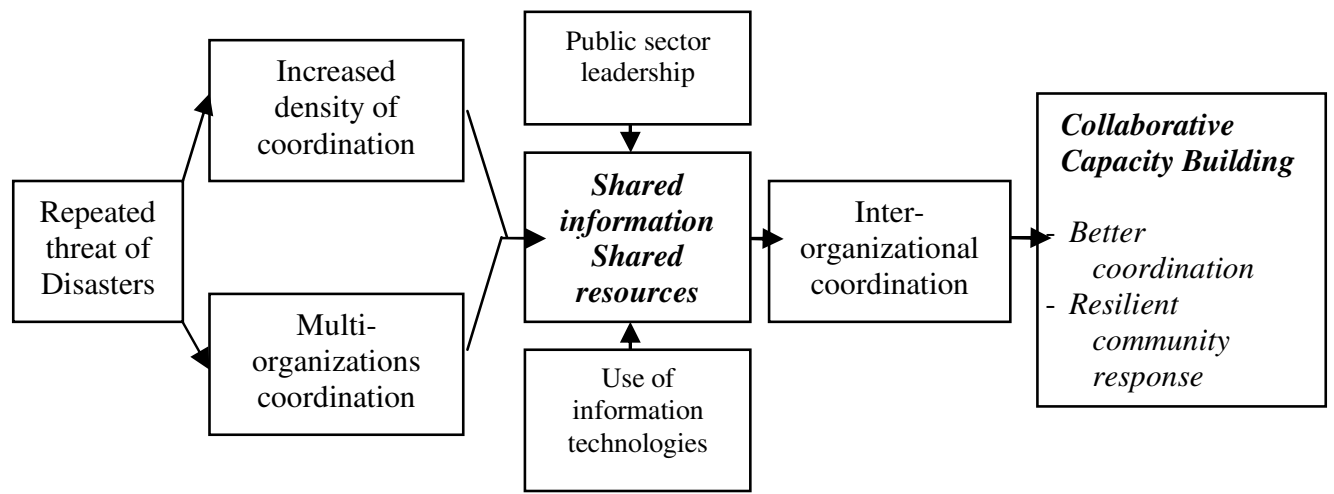

Figure 2: Organizational Learning and Coordinated Community Response to Disasters 
Public sector leadership and utilization of information technology can play an important role in this learning and network coordination (Kapucu 2006, 2009; Comfort 1999).

\section{Methods}

The authors reviewed Florida State Emergency Response Team (SERT) situation reports before, during, and after the hurricanes. SERT produced Situation Reports that were made available to the public daily and weekly that outlined current response efforts being monitored through the State Emergency Operation Center (EOC). Content analysis was conducted on all situation reports for each of the four storms. The data collection process numbered and catalogued organizations involved in the responses, the date and storm was recorded, and agency contact, sector, and source of funding were also noted. The transactions reported are focused on the response effort monitored by SERT situation reports. The Orlando Sentinel was available for content analysis and was chosen because of its proximity to three of the four major storms (Charley, Frances, and Jeanne) and its central location in the state. The three major hurricanes directly hit central Florida (see Figure 1 for the paths of the hurricanes). Because there were no reported storms in June or July of the 2004 hurricane season content analysis began with the August 1, 2004 issue and ran through November 30, 2004. Each issue was reviewed for articles that detailed community response to storm preparation, storm action, or post-storm responses. Each entry was numbered by date, the organizations were listed as separate entries and given organization numbers, the contact, sector, and source of funding were identified, and the transaction was recorded. Organizations that worked together and shared knowledge and resources to accomplish a task were noted.

Four interviews were conducted with respondents whose counties were impacted by three or more hurricanes during 2004 hurricane season. The purpose of these interviews was to assess respondents' views regarding the adequacy of current efforts and the role of emergency managers in the process. These interviews provide additional insight and understanding of current emergency management efforts.

Data collected from the content analyses were analyzed using the UCINET 6.0 social network analysis software program. UCINET is a comprehensive program for the analysis of social networks. The program contains several network analysis routines (e.g., centrality measures, dyadic cohesion measures, positional analysis algorithms, and clique etc.), and general statistical and multivariate analysis tools such as multidimensional scaling, correspondence analysis, factor analysis, cluster analysis, and multiple regression (Borgatti, Everett, and Freeman 2002). Social network analysis measures the relations in a 
network and provides a comprehensive picture of the network relationship (Mandell and Tsai 2007).

\section{Findings and Results}

Organizational learning depends on the development of a usable knowledge and information infrastructure to support inter-organizational operations among the multiple agencies that make up the potential response system. In the following section, network analysis for each hurricane individually is presented first; and second, network analysis of the system used to respond to the four hurricanes during the six week duration of the response in 2004.

\section{Multi-organizational Collaboration in Response to Four Hurricanes}

In response to Hurricane Francis, a total of 69 organizations participated in mitigation and response activities with 48 (69.7\%) being public organizations. When we examine the public organizations by jurisdictions, it shows that the majority of the organizations, 16, are county organizations, followed by state (14), city (9), federal (9), and regional (0) organizations. It is noteworthy that the second dominant group is private with 13 organizations (18.84\%). Lastly, 8 $(11.59 \%)$ were nonprofit organizations. In response to Hurricane Ivan, a total of 74 organizations participated in response and mitigation activities with the largest percentage pertaining to public organizations $(75.68 \%)$. When we examine the public organizations by jurisdictions, it shows that the majority of the organizations, 31, are county organizations, followed by state (12), federal (6), city (5), and regional (2) organizations. It is noteworthy that the second dominant group is private with 10 organizations (13.51\%). Lastly, 8 (10.81\%) were nonprofit organizations. In response to Hurricane Jeanne, a total of 95 organizations participated in response and mitigation activities with the largest percentage pertaining to public organizations $(73.68 \%)$. When we examine the public organizations by jurisdictions, it shows that the majority of the organizations, 27, are county organizations, followed by state (19), city (12), federal (11), and regional (1) organizations. It is again noteworthy that the second dominant group is private with 19 organizations (20\%). Only $6(6.32 \%)$ were nonprofit organizations.

Table 1 presents the numerical distribution of the organizations involved in response activities in 2004. In response to Hurricane Charley, a total of 144 organizations participated in mitigation and response activities with 87 (60.42\%) being public organizations. When we examine the public organizations by jurisdictions it shows that the majority of the organizations, 34, are county organizations, followed by city (20), state (18), federal (11), and regional (4). It is 
noteworthy that the second dominant group is private organizations with 47 (32.64\%). Last, 10 (6.94\%) organizations were nonprofit. Public organizations played a significant role in the response operations, followed by private; and, there didn't seem to be much interaction between organizations.

\begin{tabular}{|l|l|l|l|l|l|l|l|l|}
\hline Type & \multicolumn{2}{l}{ Charley } & \multicolumn{2}{l|}{ Frances } & \multicolumn{2}{l|}{ Ivan } & \multicolumn{2}{l|}{ Jeanne } \\
\hline & $\#$ & $\%$ & $\#$ & $\%$ & $\#$ & $\%$ & $\#$ & $\%$ \\
\hline Public-federal & 11 & $8 \%$ & 9 & $13 \%$ & 6 & $8 \%$ & 11 & $12 \%$ \\
\hline Public-state & 18 & $13 \%$ & 14 & $20 \%$ & 12 & $16 \%$ & 19 & $20 \%$ \\
\hline Public-regional & 4 & $3 \%$ & 0 & $0 \%$ & 2 & $3 \%$ & 1 & $1 \%$ \\
\hline Public-county & 34 & $24 \%$ & 16 & $23 \%$ & 31 & $42 \%$ & 27 & $28 \%$ \\
\hline Public-city & 20 & $14 \%$ & 9 & $13 \%$ & 5 & $7 \%$ & 12 & $13 \%$ \\
\hline Public-total & 87 & $60 \%$ & 48 & $70 \%$ & 56 & $76 \%$ & 70 & $74 \%$ \\
\hline Non profit & 10 & $7 \%$ & 8 & $12 \%$ & 8 & $11 \%$ & 6 & $6 \%$ \\
\hline Private & 47 & $33 \%$ & 13 & $19 \%$ & 10 & $14 \%$ & 19 & $20 \%$ \\
\hline Total & $\mathbf{1 4 4}$ & $\mathbf{1 0 0 \%}$ & $\mathbf{6 9}$ & $\mathbf{1 0 0 \%}$ & $\mathbf{7 4}$ & $\mathbf{1 0 0 \%}$ & $\mathbf{9 5}$ & $\mathbf{1 0 0 \%}$ \\
\hline
\end{tabular}

Source: content analyses of SERT situation reports and newspaper news reports.

Table 1: Organizational Response to Hurricanes in 2004

Figure 3 illustrates the numbers of organizations involved in response to the four hurricanes in 2004. Table 1 and Figure 2 show a significant decrease in the number of responding organizations from Hurricane Charley to Hurricane Ivan (the third hurricane). This can be interpreted as a sign of complacency of government agencies in coordinating the response operations. A similar trend was identified in terms of individual citizens' response to the hurricanes in 2004 by Wang and Kapucu (2008). In addition, it might also be due to the overall impact of the hurricanes, each of which had a different path and different strength. For example, while Hurricane Charley had significantly hit the State, Hurricane Ivan's impact was limited. Lastly, the lower number of organizations responding in later phases of the period may be attributed to the uniqueness of the case itself. Four consecutive hurricanes is not a situation emergency managers and responders face very often. 


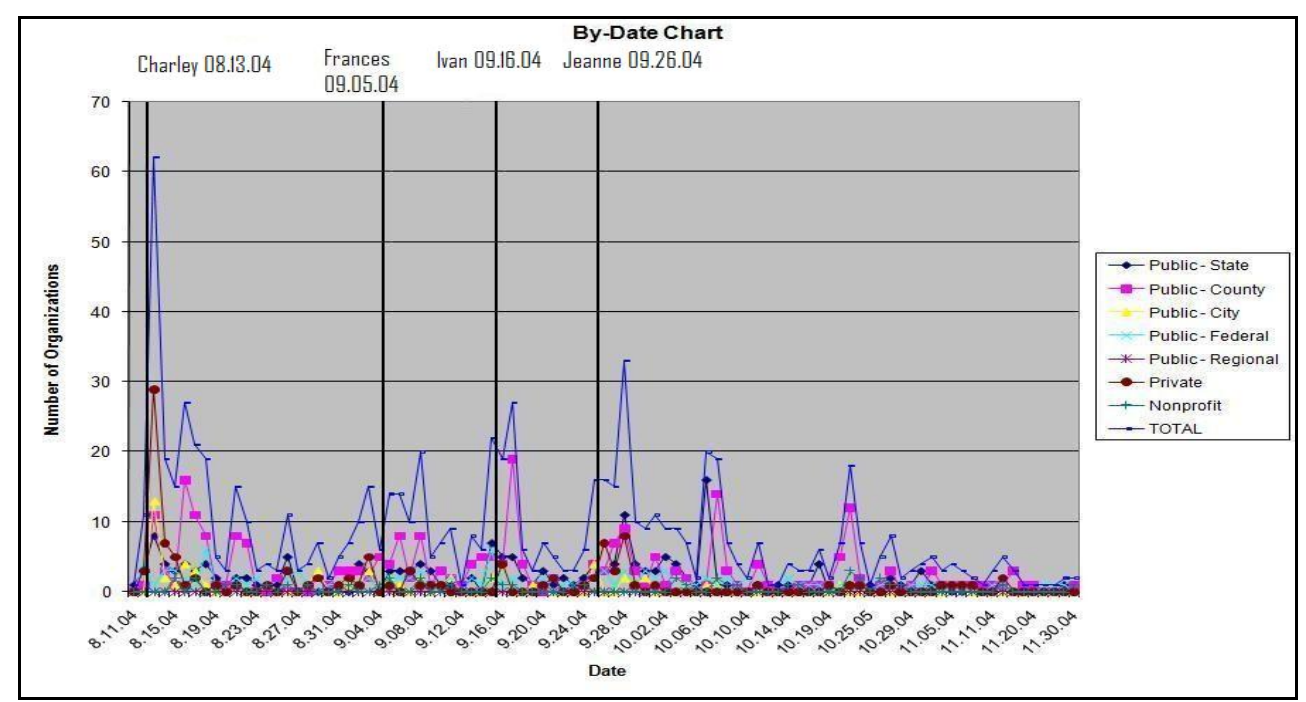

Source: content analyses of SERT situation reports and newspaper news reports.

Figure 3: Actors Involved in Response to Four Hurricanes, 08/11/04 - 11/30/04

\section{Measuring Hurricane Network Coordination: Network Analysis}

The number of organizations that responded to the four hurricanes presented in the previous section provides some valuable information about an overall picture of the response operations. The following section focuses on analyzing organizations' relationships to other agencies (actors) in the response system using network analysis tools and techniques. For example, network centralization can provide a valuable perspective. Simply speaking, degree centrality denotes the number of ties an organization has with different organizations. Organizations that have more ties with others have higher degree centrality. Network centralization is $100 \%$ when the network is a pure star network in which one actor (organization) has ties with all other actors (organizations), and all others only have one tie to the central actor (organization). In other words, in a star network, there is one central actor (organization) that holds the maximum degree of centrality while all others hold the minimum degree of centrality. Calculations for centrality during the response to the four Hurricanes show: Hurricane Charley 10.02\%; Hurricane Frances 9.58\%; Hurricane Ivan 6.14\%; Hurricane Jeanne $15.55 \%$. This summary measure of centralization is an indicator of a loosely coupled network in every case with Hurricane Ivan being the weakest. Being low on degree centrality is preferable during disaster response because it indicates there are ties between organizations and not just to a central actor (organization). More ties between organizations in a disaster response network are preferable because there is greater exchange of information and resources (see Table 2). 
In network analysis, three types of centrality reveal interesting characteristics about the network: degree centrality, closeness centrality, and betweenness centrality (Comfort and Haase 2006; Kapucu 2006). In all centrality measures mean, standard deviation, minimum, and maximum values allow evaluation of the position and role of actors in the network. Table 2 presents the measures of degree centrality. Degree centrality gives us information about the frequency of organizational interactions in the network. According to degree centrality, organizations that have more ties (interactions) will be more powerful and advantaged. Therefore it is important to observe each organization's degree centrality to determine key players.

\begin{tabular}{|c|c|c|c|c|c|c|c|c|}
\hline & \multicolumn{2}{|l|}{ Charley } & \multicolumn{2}{|l|}{ Frances } & \multicolumn{2}{|l|}{ Ivan } & \multicolumn{2}{|l|}{ Jeanne } \\
\hline $\begin{array}{l}\text { Network } \\
\text { Centralization }\end{array}$ & \multicolumn{2}{|l|}{$10.02 \%$} & \multicolumn{2}{|l|}{$9.58 \%$} & \multicolumn{2}{|l|}{$6.14 \%$} & \multicolumn{2}{|l|}{$15.55 \%$} \\
\hline Heterogeneity & \multicolumn{2}{|l|}{$5.55 \%$} & \multicolumn{2}{|l|}{$6.72 \%$} & \multicolumn{2}{|l|}{$6.64 \%$} & \multicolumn{2}{|l|}{$6.68 \%$} \\
\hline Normalized & \multicolumn{2}{|l|}{$5.06 \%$} & \multicolumn{2}{|l|}{$5.94 \%$} & \multicolumn{2}{|l|}{$5.89 \%$} & \multicolumn{2}{|l|}{$6.04 \%$} \\
\hline & Degree & $\begin{array}{l}\text { Nrm } \\
\text { Degree }\end{array}$ & Degree & $\begin{array}{l}\text { Nrm } \\
\text { Degree }\end{array}$ & Degree & $\begin{array}{l}\text { Nrm } \\
\text { Degree }\end{array}$ & Degree & $\begin{array}{l}\text { Nrm } \\
\text { Degree }\end{array}$ \\
\hline Mean & 0.77 & 0.40 & 0.69 & 0.58 & 0.51 & 0.41 & 0.77 & 0.53 \\
\hline Std Dev & 2.41 & 1.24 & 1.85 & 1.55 & 1.38 & 1.12 & 2.27 & 1.57 \\
\hline Sum & 150.00 & 77.32 & 84.00 & 70.00 & 64.00 & 51.61 & 112.00 & 77.24 \\
\hline Variance & 5.81 & 1.54 & 3.44 & 2.39 & 1.91 & 1.25 & 5.15 & 2.45 \\
\hline Minimum & 0.00 & 0.00 & 0.00 & 0.00 & 0.00 & 0.00 & 0.00 & 0.00 \\
\hline Maximum & 20.00 & 10.31 & 12.00 & 10.00 & 8.00 & 6.45 & 23.00 & 15.86 \\
\hline
\end{tabular}

NOTE: NrmDegree $=$ normed degree

10 Organizations That Have Highest Degree Centrality

\begin{tabular}{|l|l|l|l|l|l|l|l|}
\hline \multicolumn{2}{|l|}{ Charley } & Frances & \multicolumn{2}{l|}{ Ivan } & Jeanne & \\
\hline Name & Degree & Name & Degree & Name & Degree & Name & Degree \\
\hline OCOEM & 20 & FEMA & 12 & FDEM & 8 & FDEM & 23 \\
\hline FEMA & 19 & OrCG & 8 & FEMA & 7 & FEMA & 9 \\
\hline FDEM & 11 & ARC & 8 & OrCG & 6 & DCF & 8 \\
\hline OrCG & 9 & FSGGO & 8 & OCOEM & 6 & USG & 4 \\
\hline FSGGO & 8 & USG & 7 & ARC & 5 & LaCG & 4 \\
\hline ARC & 7 & OCOEM & 5 & FSGGO & 4 & OCOEM & 4 \\
\hline PEF & 6 & FNG & 4 & USG & 4 & OrCG & 4 \\
\hline USG & 4 & FDEM & 3 & LA & 2 & FSGGO & 4 \\
\hline OsCG & 4 & SJRWMD & 2 & PCC & 2 & PoC & 3 \\
\hline AC & 3 & LaCG & 2 & FNG & 2 & HCCHInc & 3 \\
\hline
\end{tabular}

Table 2: Degree Centrality Statistics for the Four Hurricanes in Florida

Closeness centrality indicates how close an actor (organization) is to all other actors (organizations) in the network (Wasserman and Faust 1994). This 
measure is useful in terms of estimating the flow of information through a network by assuming that if the actors (organizations) are close to one another that the exchange of information and sharing of resources occurs more quickly (Comfort and Haase, 2006). Closeness centrality approaches the network from the perspective of connectivity among organizations. In order to explain closeness centrality, we may use an example from the emergency response network to Hurricane Charley. FEMA supplied resources to Florida Division of Emergency Management (FDEM) for operations in response to Hurricane Charley. The federal resources were distributed by FDEM to County Emergency Operation Centers (EOCs). In this situation, Orange County EOC (OCEOC) received FEMA resources through Florida SERT; therefore, OCEOC's geodesic distance to FEMA for resource allocation appears to be two in the network analysis, meaning that OCEOC was 'two steps' away from federal resources. If OCEOC had directly received the federal resources from FEMA, its farness (geodesic distance) would have been one.

The statistics in Table 3 show high means of "farness" for all four networks which means on average all organizations are far from each other in terms of the number of steps it takes to communicate with each other. There are 144 actors in the Hurricane Charley network and the "farness" of the closest actor, Orange County Office of Emergency Management (OCOEM), is 29707; that is, calculated total geodesic distances from OCOEM to all other actors in the network is 29707. If OCOEM had direct connection to all other actors then this number would be 143 (144-1). Thus, even the closest or, the most central actor in Hurricane Charley is quite far from other actors or, has not a big centrality power in the network. The result is similar in other networks. Actors in the networks are not close; therefore, we can at least conclude that communication and coordination in the network system is not at the expected level as planned in the state and county comprehensive emergency management plans.

\begin{tabular}{|l|l|l|l|l|l|l|l|l|}
\hline \multicolumn{3}{|l}{ Charley } & \multicolumn{2}{l}{ Frances } & \multicolumn{2}{l|}{ Ivan } & Jeanne \\
\hline & inFarness & inClsnss & inFarness & inClsnss & inFarness & inClsnss & inFarness & inClsnss \\
\hline Mean & 37642.742 & 0.516 & 14307.322 & 0.841 & 15420.168 & 0.804 & 21071.082 & 0.688 \\
\hline Std Dev & 858.074 & 510.503 & 622.037 & 502.57 & 298.796 & 0.017 & 327.73 & 0.012 \\
\hline Sum & 7340335 & 100.559 & 1731186 & 101.704 & 1927521 & 100.56 & 3076378 & 100.5 \\
\hline Variance & 736291.125 & 0 & 386930.344 & 0.002 & 89279.273 & 0 & 107407.047 & 0 \\
\hline Minimum & 29707 & 0.513 & 12270 & 0.826 & 13407 & 0.8 & 18862 & 0.685 \\
\hline Maximum & 37830 & 0.653 & 14520 & 0.978 & 15500 & 0.925 & 21170 & 0.769 \\
\hline
\end{tabular}

NOTE: SSQ $=$ Sum of Squares; MCSSQ $=$ Mean Centered Sum of Squares; Euc Norm = Euclidean Norm; inClsnss $=$ inCloseness; outClsnss $=$ outCloseness 
10 Organizations That Have Highest Closeness Centrality

\begin{tabular}{|l|l|l|l|l|l|l|l|l|l|l|l|}
\hline \multicolumn{9}{|l}{ Charley } & \multicolumn{9}{l}{ Frances } & \multicolumn{2}{l|}{ Jvan } & \multicolumn{2}{l|}{ Jeanne } \\
\hline Name & Frnss & Clsns & Name & Frnss & Clsns & Name & Frnss & Clsns & Name & Frnss & Clsns \\
\hline OCOEM & 29707 & 0.653 & OCOEM & 12270 & 0.978 & OCOEM & 13407 & 0.925 & DCF & 18862 & 0.769 \\
\hline PoC & 33396 & 0.581 & SA & 12380 & 0.969 & OCCC & 14152 & 0.876 & SeCG & 18875 & 0.768 \\
\hline FEMA & 33569 & 0.578 & CiOr & 12389 & 0.969 & FEMA & 14266 & 0.869 & OCOEM & 19582 & 0.74 \\
\hline AC & 33586 & 0.578 & SJRWMD & 12392 & 0.968 & ARC & 14267 & 0.869 & PoC & 20016 & 0.724 \\
\hline OsCG & 33599 & 0.577 & WESH & 12392 & 0.968 & FNG & 14519 & 0.854 & FEMA & 20155 & 0.719 \\
\hline ARC & 36280 & 0.535 & FHP & 12400 & 0.968 & FSGGO & 14636 & 0.847 & ARC & 20592 & 0.704 \\
\hline FNG & 36285 & 0.535 & FEMA & 12489 & 0.961 & OrCG & 14636 & 0.847 & PEF & 20737 & 0.699 \\
\hline FSGGO & 36474 & 0.532 & ARC & 12492 & 0.961 & LA & 15252 & 0.813 & OS & 20737 & 0.699 \\
\hline KUA & 37057 & 0.524 & OrCG & 12495 & 0.96 & EMAC & 15253 & 0.813 & OUC & 20737 & 0.699 \\
\hline OCU & 37057 & 0.524 & FSGGO & 12503 & 0.96 & AL & 15253 & 0.813 & OsCG & 20880 & 0.694 \\
\hline
\end{tabular}

NOTE: inClsnss $=$ inCloseness

Table 3: Closeness Centrality Statistics for the Four Hurricanes in Florida

Table 4 presents the measure of betweenness centrality. Betweenness is a measure of the extent to which an actor lies in the direct path between two other actors (Wasserman and Faust 1994). It is the degree or the extent to which a node contributes to the overall sum of maximum interaction among other nodes. Having greater betweenness centrality means that more actors depend on that actor. In the example above, since FDEM connects OCOEM and FEMA it gains betweenness power. However if OCOEM and FEMA can interact directly or through another organization like the Florida State Government - Governor's Office (FSGGO) then the OCEOC will lose its betweenness power because OCEOC and FEMA have more than two optional ways to interact. For evaluation purposes it is better if the network has a smaller betweenness mean. In the absence of a bridging organization a communication breakdown will occur, because the network structure in this or another way limits direct contact and increases reliance on network peers for effective and faster results. From another perspective, some organizations like FEMA, state and county operations centers, etc. should have more betweenness power than others, because it is their responsibility to connect response activities. 


\begin{tabular}{|l|l|l|l|l|}
\hline & Charley & Frances & Ivan & Jeanne \\
\hline & Betweenness & Betweenness & Betweenness & Betweenness \\
\hline Mean & 0.774 & 2.529 & 0.52 & 0.397 \\
\hline Std Dev & 5.56 & 13.899 & 2.844 & 2.24 \\
\hline Sum & 151 & 306 & 65 & 58 \\
\hline Variance & 30.914 & 193.187 & 8.086 & 5.017 \\
\hline Minimum & 0 & 0 & 0 & 0 \\
\hline Maximum & 69.833 & 111 & 24 & 20 \\
\hline $\begin{array}{l}\text { Network } \\
\text { Centralization Index }\end{array}$ & $0.19 \%$ & $0.77 \%$ & $0.16 \%$ & $0.09 \%$ \\
\hline
\end{tabular}

10 Organizations That Have Highest Betweenness Centrality

\begin{tabular}{|l|l|l|l|l|l|l|l|}
\hline \multicolumn{3}{l|}{ Charley } & \multicolumn{2}{l}{ Frances } & Ivan & \multicolumn{2}{l|}{ Jeanne } \\
\hline Name & Btwnss & Name & Btwnss & Name & Btwnss & Name & Btwnss \\
\hline FEMA & 69.833 & OrCG & 111 & OrCG & 24 & EMAC & 20 \\
\hline OrCG & 22 & FEMA & 86 & FEMA & 14.5 & DCF & 14 \\
\hline AC & 20 & FSGGO & 47.5 & FSGGO & 14 & PoC & 11 \\
\hline FSGGO & 15.5 & ARC & 45 & FDEM & 6.5 & OrCG & 4 \\
\hline PEF & 9 & FNG & 11 & ARC & 4 & FSGGO & 4 \\
\hline OsCG & 6.5 & SJRWMD & 5.5 & FNG & 2 & SLCG & 2 \\
\hline ARC & 4 & AZ & 0 & AZ & 0 & BCGov & 1 \\
\hline HHS & 2 & CT & 0 & AK & 0 & SeCG & 1 \\
\hline VoCG & 0.5 & CO & 0 & DC & 0 & PEF & 0.5 \\
\hline SeCG & 0.5 & FL & 0 & FL & 0 & OUC & 0.5 \\
\hline
\end{tabular}

NOTE: Btwnss $=$ Betweenness

Table 4: Betweenness Centrality Statistics for the Four Hurricanes in Florida

For Hurricane Charley, the maximum betweenness is 69.833 while the mean of betweenness for the network is 0.774 , and standard deviation of the network is 5.560. The network centralization index is $0.19 \%$. This shows the overall betweenness power is significantly low. That means an actor in the network is not very dependent on some actors if it desires to communicate with others. For hurricane Frances, the maximum betweenness is 111.000 while the mean of betweenness for the network is 2.529, and standard deviation of the network is 13.899 . The network centralization index is $0.77 \%$ and this shows the overall betweenness power is significantly low. Again, that means an actor in the network is not very dependent on some actors to communicate with others. Based on the closeness data presented above, it seems that no organization is dependent on any other single organization for communication with others, but many organizations in the network do need somebody for communication with others. Organizations just have a choice, decreasing dependence on one, but the need for somebody to broker communication is still there. For Hurricane Ivan, the maximum betweenness is 24.000 while the mean of betweenness for the network 
is 0.520. And standard deviation of the network is 2.844. The network centralization index is $0.16 \%$ which shows the overall betweenness power is significantly low. That again means an actor in the network is not very dependent on some actors to communicate with others. For Hurricane Jeanne, the maximum betweenness is 20.000 while the mean of betweenness for the network is 0.397 . And, the standard deviation of the network is 2.240. The network centralization index is $0.09 \%$. This shows the overall betweenness power is significantly low. And, that one more time means an actor in the network is not very dependent on some actors to communicate with others.

\section{Cliques as Subsets in a Coordination Network}

Cliques are subsets of networks that develop recurring patterns of interaction in the conduct of disaster operations. They are important in understanding the constraints on the network. They usually develop in an effort to facilitate action under stress; however, they may also inhibit the full exchange of information and resources with other organizations in the network by excluding some from exchange (Comfort and Haase, 2006). UCINET analysis identified cliques composed of at least 3 organizations in the response network. Conversely, cliques exemplify a fully collaborative sub-network in which all actors have a link with each other. Therefore, in terms of organizational learning it could be argued that since cliques represent a closely working subgroup dissemination of information and knowledge between members of the clique should occur more easily. In other words, coordination in the network is more likely to happen in closely working subgroups or cliques.

\begin{tabular}{|c|c|c|c|}
\hline & Public & Private & Nonprofit \\
\hline \multirow{7}{*}{ Charley } & $\begin{array}{l}\text { Federal Emergency Management Agency, Florida Division of } \\
\text { Emergency Management, Orange County Government, Orange } \\
\text { County Office of Emergency Management }\end{array}$ & & \\
\hline & $\begin{array}{l}\text { Federal Emergency Management Agency, Florida State } \\
\text { Government - Governor's Office, Orange County Government, } \\
\text { Orange County Office of Emergency Management }\end{array}$ & & \\
\hline & $\begin{array}{l}\text { Florida Division of Emergency Management, Orange County } \\
\text { Government, Orange County Office of Emergency Management }\end{array}$ & & $\begin{array}{l}\text { American } \\
\text { Red Cross }\end{array}$ \\
\hline & $\begin{array}{l}\text { Orange County Government, Orange County Office of } \\
\text { Emergency Management, }\end{array}$ & $\begin{array}{l}\text { Orlando } \\
\text { Sentinel }\end{array}$ & \\
\hline & $\begin{array}{l}\text { AmeriCorps, Federal Emergency Management Agency, Osceola } \\
\text { County Government }\end{array}$ & & \\
\hline & $\begin{array}{l}\text { Charlotte County Emergency Management, Federal Emergency } \\
\text { Management Agency, Florida State Government - Governor's } \\
\text { Office }\end{array}$ & & \\
\hline & $\begin{array}{l}\text { Federal Emergency Management Agency, Florida Division of } \\
\text { Emergency Management, Lake County Government }\end{array}$ & & \\
\hline
\end{tabular}




\begin{tabular}{|c|c|c|c|}
\hline & Public & Private & Nonprofit \\
\hline \multirow{11}{*}{ Frances } & $\begin{array}{l}\text { Federal Emergency Management Agency, Florida Division of } \\
\text { Emergency }\end{array}$ & & $\begin{array}{l}\text { American } \\
\text { Red Cross }\end{array}$ \\
\hline & $\begin{array}{l}\text { Federal Emergency Management Agency, Lake County } \\
\text { Government }\end{array}$ & & $\begin{array}{l}\text { American } \\
\text { Red Cross }\end{array}$ \\
\hline & $\begin{array}{l}\text { Federal Emergency Management Agency, Orange County } \\
\text { Government }\end{array}$ & & $\begin{array}{l}\text { American } \\
\text { Red Cross }\end{array}$ \\
\hline & Federal Emergency Management, United States Government & & $\begin{array}{l}\text { American } \\
\text { Red Cross }\end{array}$ \\
\hline & $\begin{array}{l}\text { Federal Emergency Management Agency, Florida National } \\
\text { Guard, Florida State Government - Governor's Office }\end{array}$ & & \\
\hline & $\begin{array}{l}\text { Federal Emergency Management Agency, Florida Division of } \\
\text { Emergency Management, Florida State Government - Governor's } \\
\text { Office }\end{array}$ & & \\
\hline & $\begin{array}{l}\text { Federal Emergency Management Agency, Florida State } \\
\text { Government - Governor's Office, Orange County Government }\end{array}$ & & \\
\hline & $\begin{array}{l}\text { Federal Emergency Management Agency, Florida State } \\
\text { Government - Governor's Office, United States Government }\end{array}$ & & \\
\hline & $\begin{array}{l}\text { Federal Emergency Management Agency, Orange County } \\
\text { Government }\end{array}$ & & $\begin{array}{l}\text { Salvation } \\
\text { Army }\end{array}$ \\
\hline & $\begin{array}{l}\text { Florida National Guard, Florida State Government - Governor's } \\
\text { Office, Orange County Office of Emergency Management }\end{array}$ & & \\
\hline & $\begin{array}{l}\text { Florida State Government - Governor's Office, Orange County } \\
\text { Office of Emergency Management, United States Government }\end{array}$ & & \\
\hline \multirow{4}{*}{ Ivan } & $\begin{array}{l}\text { Federal Emergency Management Agency, Florida Division of } \\
\text { Emergency Management, Orange County Office of Emergency } \\
\text { Management }\end{array}$ & & \\
\hline & $\begin{array}{l}\text { Federal Emergency Management Agency, Florida Division of } \\
\text { Emergency Management, United States Government }\end{array}$ & & \\
\hline & $\begin{array}{l}\text { Florida Division of Emergency Management , Orange County } \\
\text { Office of Emergency Management }\end{array}$ & & $\begin{array}{l}\text { American } \\
\text { Red Cross }\end{array}$ \\
\hline & $\begin{array}{l}\text { Louisiana, Division of Emergency Management, United States } \\
\text { Government }\end{array}$ & & \\
\hline \multirow{3}{*}{ Jeanne } & $\begin{array}{l}\text { Federal Emergency Management Agency, Florida Division of } \\
\text { Emergency Management, Orange County Office of Emergency } \\
\text { Management }\end{array}$ & & \\
\hline & $\begin{array}{l}\text { Federal Emergency Management Agency, Florida Division of } \\
\text { Emergency Management, St. Lucie County Government }\end{array}$ & & \\
\hline & $\begin{array}{l}\text { Federal Emergency Management } \\
\text { Government, Polk County }\end{array}$ & & \\
\hline
\end{tabular}

Table 5: Organizational Cliques Identified in Response to Hurricanes

\section{Visual Representation of Network Coordination}

Communications among different agencies and jurisdictions were difficult just before and during the first and the second storm.1 By the third storm, however,

1 Interview with State Emergency Management Division, June 6, 2005. 
organizations were very good at communicating. The agencies that participated in coordination include the Sheriff's office, local fire departments, municipalities, road crews, and the public. One of the examples is that the city worked with citizens who were engaged within each neighborhood, trained those citizens, and provided neighborhood key leaders with updates on what was being done. Finally, the use of Community Emergency Response Teams (CERT) in every neighborhood provided a close social connection to those members of the community who may have been disconnected from the community at large, such as those who do not speak English, the poor, and the homeless (Weaver 2004).

Three months before the hurricanes, the City of Orlando had a series of table top exercises, sat down with key players and discussed the impact on Central Florida. During the exercises, the City brought in public works personnel and contractors, who were responsible for debris removal. They went through the process, demonstrated coordination, and answered important questions. Such early preparedness efforts significantly helped during the hurricanes.2 Howwever, one of the biggest difficulties was still communication among different neighborhood groups. Orange County did not have the inner connectivity during the hurricanes because neighborhood services were not a part of the EOC. After several hurricanes, the County had inner connectivity.3 The Seminole County public safety director repeatedly mentioned the importance of information technology utilization among responding agencies and coordination with other jurisdictions, neighboring counties, for example.4

2 Interview with City of Orlando, Office of Emergency Management, June 30, 2005

3 Interview with Orange County Office of Emergency Management, July 19, 2005.

4 Interview with Seminole County, Office of Emergency Management, July 15, 2005. 


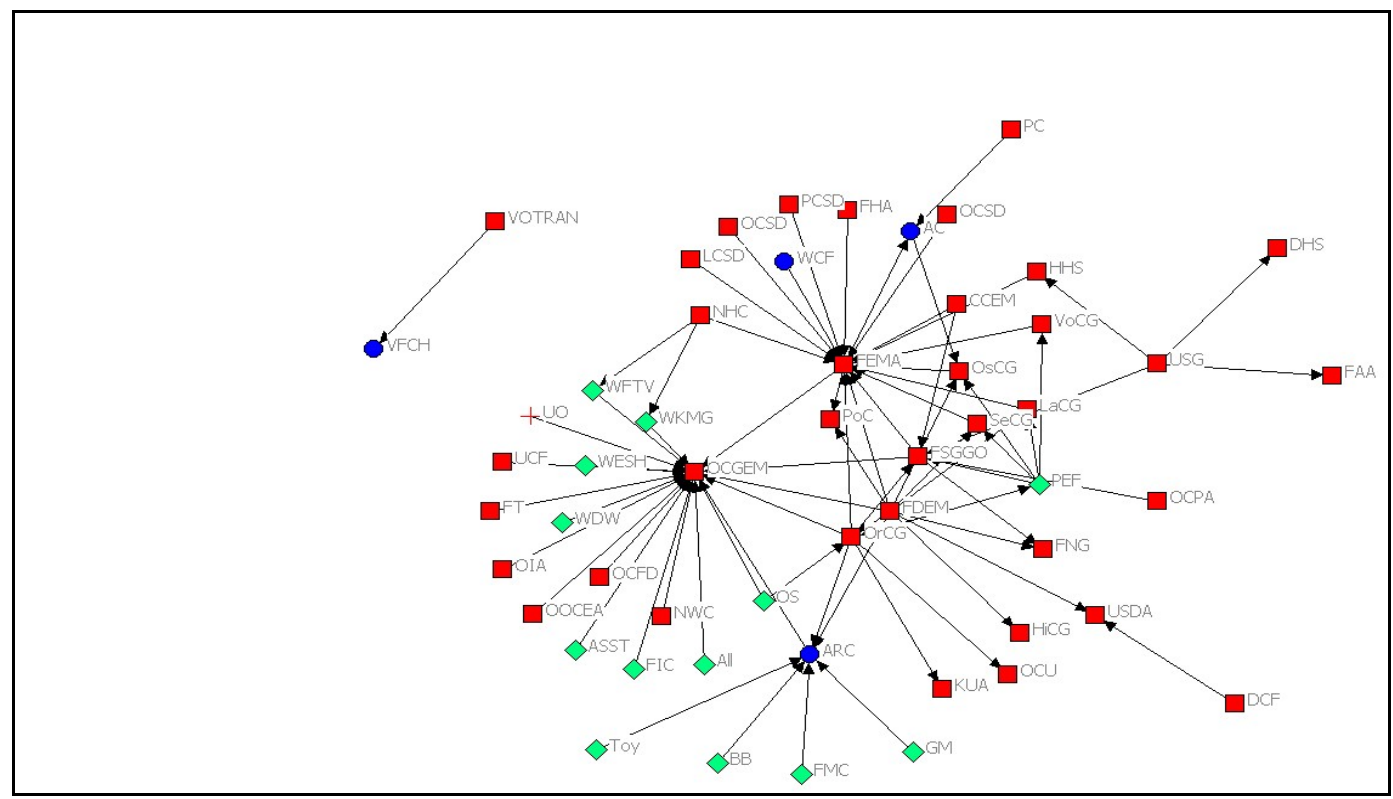

NOTE: See the appendix 1 for abbreviations. Circles (or blue) $=$ Nonprofits, Squares $($ or red $)=$ Public, Diamonds $($ or green $)=$ Privat

Figure 4: Inter-organizational Network in Response to Hurricane Charley

Figure 4 depicts the overall network of 144 organizations interacting in response to Hurricane Charley. Only 53 of 144 organizations identified in the content analyses that they interacted, communicated, and shared resources with at least one other organization in response to Hurricane Charley. By interaction we mean inter-organizational communication, sharing information, exchanging resources, or other forms of interaction. An analysis of network centrality identifies those actors who are the most important in shaping the performance of the network, as they have most ties with other actors (Wasserman and Faust 1994). In this diagram we observe that FEMA and OCOEM played central roles in the network. ARC, FSGGO, and FDEM can be counted as second-degree central actors. Also, it should be noted that many actors have only one connection and that single connection is with one of the central actors. 


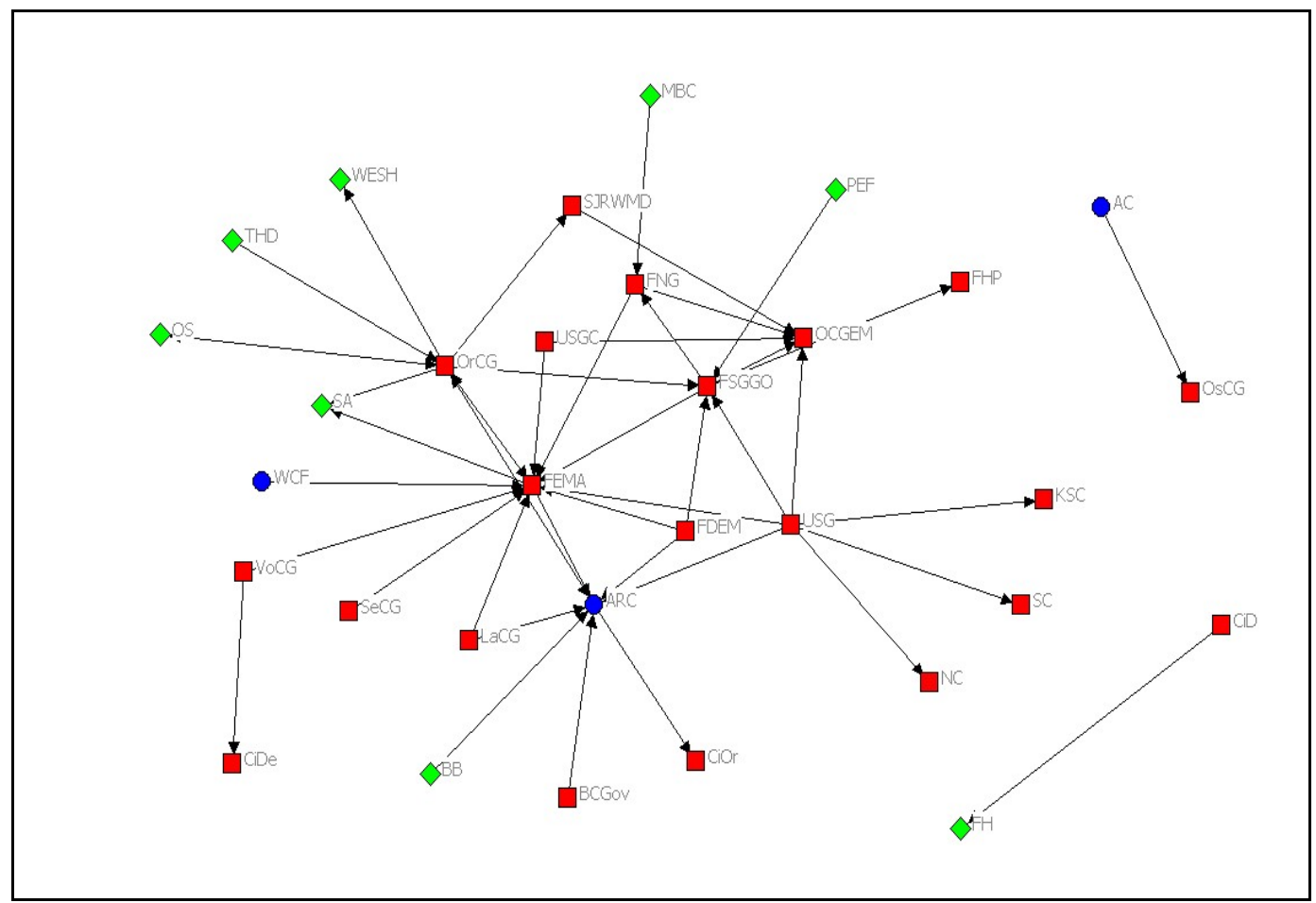

NOTE: See the appendix 1 for abbreviations. Circles (or blue) = Nonprofits, Squares $($ or red $)=$ Public, Diamonds $($ or green $)=$ Private

Figure 5: Inter-organizational Network in Response to Hurricane Frances

Figure 5 depicts the overall network of 69 organizations interacting in response to Hurricane Frances. Only 32 of 69 organizations identified in the content analyses that they interacted, communicated and shared resources with at least one other organization in response to Hurricane Frances. In this network it can quickly be seen that FEMA is the most central actor, which mainly performs liaison duty. We observe FEMA creates an interaction or communication circle around itself. Within this first level circle there are some additional key actors like ARC, OCOEM, FSGGO, and OrCG that jointly create a second-level circle. Firstlevel actors have direct connection to FEMA whereas second-level actors are two steps away from FEMA. This means that they are connected to FEMA through another organization in first-level circle. First-level circle actors generally interacted with each other; however, second-level circle actors did not. 


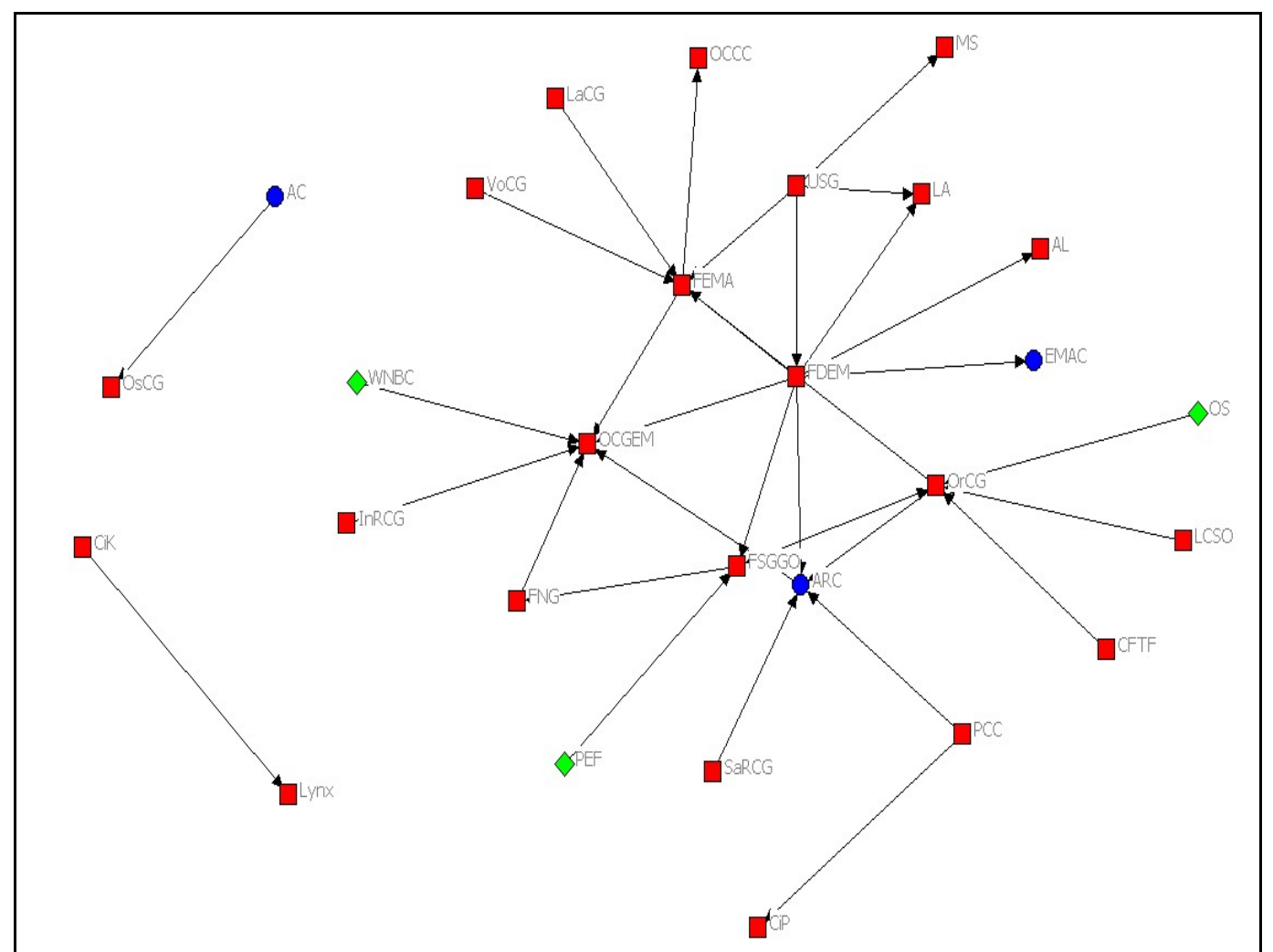

NOTE: See the appendix 1 for abbreviations. Circles (or blue) $=$ Nonprofits, Squares $($ or red $)=$ Public, Diamonds $($ or green $)=$ Private

Figure 6: Inter-organizational Network in Response to Hurricane Ivan

Figure 6 depicts the overall network of 74 organizations interacting in response to Hurricane Ivan. Only 28 of 74 organizations identified in the content analyses that they interacted, communicated, and shared resources with at least one other organization in response to Hurricane Ivan. At the very center of this network we see FDEM. Although it does not have more connections than other central players such as OCOEM, ARC, FEMA OrCG, FSGGO, it creates an interaction circle that puts it at the center of the network. 


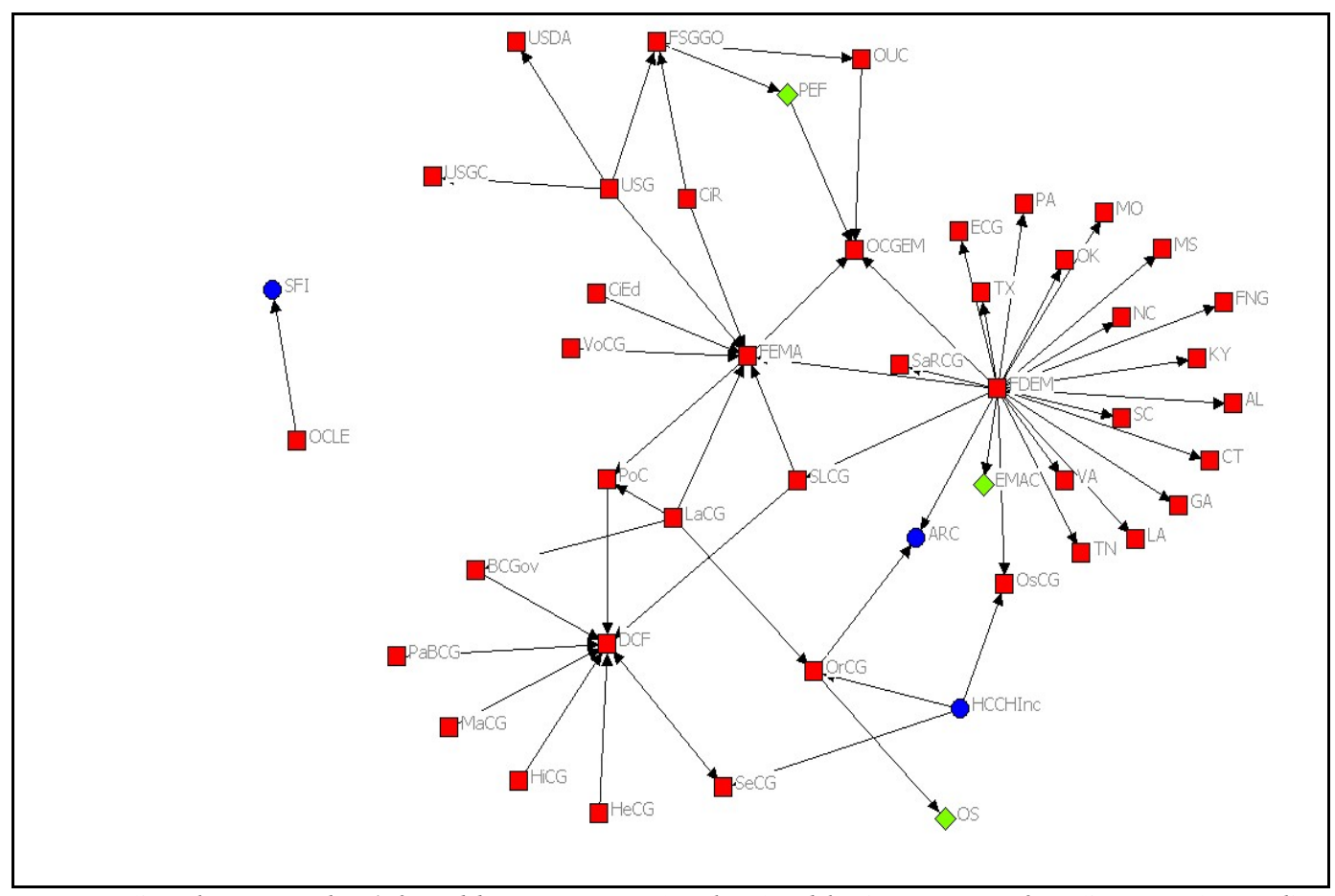

NOTE: See the appendix 1 for abbreviations. Circles (or blue) $=$ Nonprofits, Squares $($ or red $)=$ Public, Diamonds (or green $)=$ Private

Figure 7: Inter-organizational Network in Response to Hurricane Jeanne

Figure 7 depicts the overall network of 95 organizations interacting in response to Hurricane Jeanne. Only 47 of 95 organizations identified in the content analyses that they interacted, communicated and shared resources with at least one other organization in response to Hurricane Jeanne. When compared to networks of other hurricanes, Hurricane Jeanne's network differs from others. For example, some big groups are separated from the main network; and, in these groups there are many actors connected to only other one actor that connects the group to the main network. This makes the network more vulnerable, because if one of the central players becomes dysfunctional, many actors will be disconnected from the main network. For instance, what would happen if FDEM experienced a communication problem, which is quite possible in a disaster like hurricane?

Organizational coordination strategies employed are an important part of community coordination and disaster response. Before Hurricane Charley in August 2004 the last hurricane to make landfall was Irene in 1999, and one tropical storm each in the 2001 and 2002 seasons. The irregular occurrence of tropical activity prior to the 2004 hurricane season preconditioned emergency managers, public officials, and the public to take stable conditions for granted. In 
preparation for the 2004 hurricane season, the City of Orlando practiced their "response" to a large Category 4 hurricane that crossed the central section of the state causing excessive wind damage to homes and trees and flooding.5 This exercise was followed up by Hurricane Charley, a Category 4 hurricane - the first to cross Central Florida since 1969.

\section{Conclusion}

This article addressed inter-organizational coordination and its impact on collaborative capacity building in disaster environments. The study examined four networks comprised of hurricane response operations, drawing on content analyses of news and situation reports. Content analyses provided interorganizational interactions that are subject to network analysis revealing information about: (1) how critical actors interacted and coordinated, (2) subgroups under each network, and (3) each network as a system. Using network analysis in analyzing disaster response systems is a new way of exploring the issues from another perspective and through a new methodology. The article showcases the potential use of network analysis in both organizational and emergency management research.

Effectiveness in this study is defined as collaborative capacity building in response to disasters and emergencies. Organizational learning offers a mode of improving inter-organizational coordination in response to disasters in building capacity. This research acknowledges that change in performance needs to occur within organizations, among organizations within a single jurisdiction, and between jurisdictions engaged in response to disasters. The research builds on the human ability to learn and adapt to new information, but acknowledges that this capacity can only occur with the support of an appropriate information infrastructure. Complex disaster response operations lie beyond the capacity of an individual organization and require a coordinated effort. Organizations in response to four hurricanes in six weeks needed to identify sources of information, collect information, make sense of information and confer meaning, to put knowledge into action based on experience.

The network analysis conducted was based on situation reports and news articles. It indicates that there was no significant difference among coordinated response to four hurricanes. In other words, there was a failure to learn at the network level. Reasons for this failure can be considered from an organizational perspective, as well as from the network-level analysis. Research has shown that organizations in the midst of or immediately following a crisis are not ready to learn (Donahue and Tuohy 2006). For instance, Kovoor-Misra and Nathan (2000)

5 Interview with City of Orlando, Office of Emergency Management, June 30, 2005 
suggest that organizations will go through three phases following a crisis: defensiveness, openness, and forgetfulness. The organization will most likely seek to engage in a reflective learning process in the openness phase. Before that, organization members are likely to be defensive, trying to insulate themselves and their organization from criticism. Over time, the organizations will move to a period where the members feel comfortable asking questions about what happened, what values embedded in the organization might detract from performance, and so on. However, this phase is fleeting, as organizations seek to return to their normal routine (Roux-Dufort 2000) and forget the need for possible change.

Kovoor-Misra and Nathan (2000) raise an important question for learning during repeated threats of disaster. How much time is necessary for learning to occur, where openness to change is prolonged? In the case of Florida hurricanes, we suggest there was not enough time between storm systems to allow organizations and the entire response network to openly question values, relations, or performance. It is also possible that the initial network structure did not allow for collaborative learning activity, in which multiple organizations would reflect with each other to consider values, relations, and performance. The closeness centrality figures showed that actors within the network were not 'close enough' to each other for better and more effective interaction and network coordination. There was relatively little close contact among most of the organizations providing emergency response services.

Thus, one recommendation might be for more pre-season planning, open communication among emergency managers and elected officials, and the use of technology to provide for a more connected and coordinated response. Interview respondents discussed such activity, which enabled a certain level of coordinated response; however, more may be necessary to encourage learning in the event of repeated disasters. The repeated disaster scenario suggests that emergency managers must vigilantly work to keep the public agencies, nonprofit organizations, and private organizations informed and apprised of the seriousness of the situation.

One of the important limitations of this study is the use of secondary sources that might be biased in this or another sense. While it is acknowledged that situational reports and Orlando Sentinel are potential sources for bias, it was still important to have an outsider view and perspective rather than be subject to a specific organization's perceptions. It is strongly believed that secondary sources are more objective than specific agencies' possible comments from interviews or surveys administered for that purpose. Moreover, situational reports were not prepared as a response to our study and were merely a result of agencies' daily operations, which makes them more objective. It was also within the limits of the research capabilities that the authors used only two sources for the study. 


\begin{tabular}{|c|c|}
\hline$A C$ & $\Delta$ maricorn \\
\hline $\mathrm{AK}$ & Almencoips \\
\hline $\mathrm{AL}$ & Alaska \\
\hline ARC & Alabama \\
\hline ARC & American Red Cross \\
\hline $\mathrm{AZ}$ & Arizona \\
\hline BCGov & Brevard County Government \\
\hline $\mathrm{CiOr}$ & City of Orlando \\
\hline $\mathrm{CO}$ & Colorado \\
\hline CT & Connecticut \\
\hline DC & District of Columbia \\
\hline DCF & Department of Children and Families \\
\hline EMAC & Emergency Management Assistance Compact \\
\hline FDEM & Florida Division of Emergency Management \\
\hline FEMA & Federal Emergency Management Agency (FEMA) \\
\hline FHP & Florida Highway Patrol \\
\hline FL & Florida \\
\hline FNG & Florida National Guard \\
\hline FSGGO & Florida State Government - Governor's Office \\
\hline HCCHInc & Health Care Center for Homeless Inc. \\
\hline HHS & Health and Human Services \\
\hline KUA & Kissimmee Utility Authority \\
\hline LA & Louisiana \\
\hline $\mathrm{LaCG}$ & Lake County Government \\
\hline OCCC & Orange County Convention Center \\
\hline OCOEM & Orange County Office of Emergency Management \\
\hline OCU & Orange County Utilities \\
\hline OrCG & Orange County Government \\
\hline OS & Orlando Sentinel \\
\hline OsCG & Osceola County Government \\
\hline OsCSD & Osceola County School District \\
\hline OUC & Orlando Utilities Commission \\
\hline PCC & Pensacola Civic Center \\
\hline PEF & Progress Energy Florida \\
\hline $\mathrm{PoC}$ & Polk County \\
\hline SA & Salvation Army \\
\hline $\mathrm{SeCG}$ & Seminole County Government \\
\hline SJRWMD & St Johns River Water Management District \\
\hline SLCG & St. Lucie County Government \\
\hline USGC & United States Government - Congress \\
\hline VoCG & Volusia County Government \\
\hline WESH & WESH-Channel 2 \\
\hline
\end{tabular}




\section{References}

Agranoff, Robert and Michael McGuire. 2003. Collaborative public management: New strategies for local governments. Washington D.C.: Georgetown University Press.

Argote, Linda. 1999. Organizational learning: Creating, retaining, and transferring knowledge. Kluwer Academic Publishers, Boston, MA.

Argyris, Chris and Donald. A. Schon. 1996. Organizational learning II: Theory, method, and practice. Reading MA: Addison-Wesley.

. 1978. Organizational learning: A theory in action perspective. Reading MA: Addison-Wesley.

Axelrod, Robert. 1997. The complexity of cooperation: agent-based models of competition and collaboration. Princeton, N.J.: Princeton University Press.

Bazerman, Max H. and Michael D. Watkins. 2004. Predictable surprises: The disaster you should have seen coming and how to prevent them. Boston: Harvard Business School Press.

Birkland, Thomas. 2006. Lessons of disaster: Policy change after catastrophic events. Washington D.C.: Georgetown University Press. . 1997. After disaster: Agenda setting, public policy, and focusing events. Washington DC: Georgetown University Press.

Berry, Frances S., Ralph S. Brower, Ok S. Choi, Wendy X. Goa, HeeSoun Jang, Myungjung Kwon and Jessica Word. 2004. Three traditions of network research: What the Public Management Research Agenda can learn from other research communities. Public Administration Review 64 (5): 539-552.

Blatner, Keith, Matthew Carroll, Steven Daniels, and Greg Walker. 2001. Evaluating the application of collaborative learning to the Wenatchee fire recovery planning effort. Environmental Impact Assessment Review 21: 221236.

Borgatti, Stephen P., Martin G. Everett and Linton C. Freeman. 2002. UCINET 6.0 VERSION for Windows: Software for social network analysis. Harvard: Analytic Technologies.

Buchanan, Mark. 2002. Nexus: Small Worlds and the Groundbreaking Theory of Networks. New York: Norton.

Burby, Raymond J. 1998. Natural Hazards and Land Use: An Introduction. In R.J. Burby (ed.) Cooperating with Nature: Confronting Natural Hazards with Land-Use and Planning for Sustainable Communities. Joseph Henry Press, Washington, DC.

Busenberg, George J. 2001. Learning in organizations and public policy. Journal of Public Policy 21 (2): 173-89.

Carley, Kathleen M. and John R. Harrald. 1997. Organizational learning under fire: Theory and practice, American Behavioral Scientist 40 (3): 310-332. 
Cohen, William M. and Daniel A. Levinthal. 1990. Absorptive capacity: A new perspective on learning and innovation, Administrative Science Quarterly 35:128-152.

Comfort, Louise. K. 1999. Shared risk: Complex systems in seismic response. New York: Prgamon Press.

. 1996. Self-organization in disaster response: The great Hanshin, Japan earthquake of January 17, 1995. Natural Hazards Center Quick Response Report \#78. Boulder, CO: University of Colorado.

. 1994. Risk and resilience: Inter-organizational learning following the Northridge earthquake of January 17, Journal of Contingencies and Crisis Management 2 (3): 174-188.

Comfort, Louise. K. and Thomas W. Haase. 2006. Communication, coherence, and collective action: The impact of hurricane Katrina on communications infrastructure. Public Works Management and Policy 10 (3): 328-343.

Comfort, Louise K. and Naim Kapucu. 2006. Inter-organizational coordination in extreme events: The World Trade Center attack, September 11, 2001. Natural Hazards: Journal of the International Society for the Prevention and Mitigation of Natural Hazards 39 (2): 309-327.

Corbacioglu, Sitki and Naim Kapucu. 2006. Organizational learning and selfadaptation in dynamic environments of disasters. Disasters: The Journal of Disaster Studies, Policy, and Management 30 (2): 212-33.

Cyert, Richard and James March. 1963. A behavioral theory of the firm. Englewood Cliffs, NJ: Prentice-Hall.

Daniels, Steven, and Gregg B. Walker. 2001. Working through environmental conflict: The collaborative learning approach. Westport, CT: Praeger.

Detwiler, Steve. 2004. Hurricane Charley and Frances: Advice from the front lines. The FEPA Alert. Tallahassee, FL: Florida Emergency Preparedness Association, $\quad$ Winter $\quad 2004$ : $10 \quad$ (1). http://www.fepa.org/05winternewsletter.pdf. [accessed on October 24, 2007].

Donahue, Amy K. and Robert V. Tuohu. 2006. Lessons we don't learn: A study of the lessons of disasters, why we repeat them, and how we can learn them. Homeland Security Affairs 2 (2): 1-28.

Drabek, Thomas. E. 2003. Strategies for coordinating disaster responses. Boulder, CO: University of Colorado, Natural research and Applications Information Center. . 1987. The professional emergency manager: Structures and strategy for success, monograph no 44, Institute of Behavioral Science, University of Colorado, Boulder.

Durland, Maryann M. and Kimberly A. Fredericks. 2006. Social Network Analysis in Program Evaluation : New Directions for Evaluation. San Francisco: Jossy-Bass. 
Dynes, Russell. R. and Kathleen J. Tierney, eds. 1994. Disasters, collective behavior, and social organization. Newark, Deleware:University of Delaware Press.

Elliot, Dominic, Denis Smith, and Martina McGuinness. 2000. Exploring the Failure to Learn: Crises and the Barriers to Learning. Review of Business, 21(3/4), 17-24.

Federal Emergency Management Agency (FEMA). 2005. Florida's Disaster Recovery Operations by Numbers. Available online at http://www.fema.gov/news/newsrelease.fema?id=17796 [accessed on October 24, 2007].

Fitzpatrick, Peter. 1999. Natural disasters: Hurricanes. Santa Barbara, CA: ABC-CLIO.

Flin, Rhona, Eduardo Salas, Michael Strub, and Lynne Martin. 1997. Decision making under stress: Emerging themes and applications. Aldershot: Asgate Publishing.

Florida Division of Emergency Management (FDEM). 2004. The state of Florida comprehensive emergency management plan 2004. http://floridadisaster.org/documents/CEMP/floridaCEMP.htm [accessed on October 21, 2007].

Florida State Emergency Response Team (SERT). 2004a. Situation Reports. Available online at http://www.floridadisaster.org/eoc/archive.htm.

Garvin, David A. 1993. Building learning organizations. Harvard Business Review 71:78-91.

Goh, Swee. C. 1998. Toward a learning organization: The strategic building blocks. S. A. M., Advanced Management Journal 63:15-20.

Gray, Barbara. 1989. Collaborating. San Francisco: Jossey-Bass Publishers.

Holland, John. 1998. Emergence: From Chaos to Order. New York: Basic Books.

Janis, Irving. 1989. Crucial Decisions: Leadership in Policymaking and Crisis Management. New York: The Free Press.

Jones, Bryan D. 2001. Politics and the architecture of choice: Bounded rationality and governance. Chicago: University of Chicago Press.

Kapucu, Naim. 2009. Inter-organizational Coordination in Complex Environments of Disasters: The Evolution of Intergovernmental Disaster Response Systems, Journal of Homeland Security and Emergency Management: Vol. 6 : Iss. 1, Article 47. . 2006. Interagency communication networks during emergencies: Boundary spanners in multi-agency coordination. American Review of Public Administration 36 (2): 207-225.

Kapucu, Naim and Montgomery Van Wart. 2006. The emerging role of the public sector in managing extreme events: Lessons learned. Administration and Society 38 (3): 279-308. 
Kauffman, Stuart A. 1993. The origins of order: Self-organization and selection in evolution. New York: Oxford University Press.

Kayes, Christopher D. 2004. The 1996 Mount Everest climbing disaster: The breakdown of learning in teams. Human Relations 57 (10): 1263-1284.

. 2002. Proximal team learning: Lessons from United flight 93 on 9/11. Organizational Dynamics 32 (1): 80-92.

Kettl, Donald F. 2004. System under stress: Homeland security and American politics. Washington DC: CQ Press.

Khademian, Anne M. 2004. Strengthening state and local terrorism prevention and response. In The department of homeland security's first year: A report card, ed. D. Kettl, 97-117. Washington DC: The Century Foundation.

Kickert, Walter J. M., Eric-Hans Klijn, and Joop F. M. Koopanjan, eds. 1997. Managing complex networks: Strategies for the public sector. London: Sage.

Kiel, Douglas L. 1994. Managing chaos and complexity in government: A new paradigm for managing change, innovation, and organizational renewal. San Francisco: Jossey- Bass Publishers.

Kilduff, Martin and Wenpin Tsai. 2007. Social Networks and Organizations. Los Angeles: SAGE.

Kim, Linsu. 1998. Crisis construction and organizational learning: Capability building in catching-up at Hyundai Motor. Organization Science 9 (4): 506521.

Kingdon, John. W. 1995. Agendas, alternatives, and public policies, 2nd ed. New York: HarperCollins.

Kovoor-Misra, Sarah and Maria Nathan. 2000. Timing is Everything: The Optimal Time to Learn from Crises. Review of Business 21(3/4), 31-36.

Levin, Daniel. Z. and Cross, Rob. 2004. The Strength of Weak Ties You Can Trust: The Mediating Role of Trust in Effective Knowledge Transfer. Management Science 50(11): 1477-1490.

Mackenzie, Kenneth D. 1991. The Organizational hologram: The effective management of organizational change. Boston: Kluwer Academic Publishers.

Mandell, Myrna and Keast, Robyn L. 2007. Evaluating Network Arrangements: Toward Revised Performance Measures. Public Performance \& Management Review 30(4): 574-597.

MCEER. 2002. Management of Complex Civil Emergencies and Terrorism Resistant Civil Engineering Design. Proceedings from the MCEER Workshop on Lessons from the World Trade Center Terrorist Attack.

McEntire, David A. 2002. Coordinating multi-organizational responses to disaster: Lessons from the March 28, 2000, Forth Worth Tornedo. Disaster Prevention and Management 11 (5): 369-379. 
McLoughlin, David. 1985. A Framework for integrated emergency management, Public Administration Review. 45, Special Issue: Emergency management: A challenge for public administration. (January): 165-172.

Mileti, Dennis S. 1999. Disasters by design: A reassessment of natural hazards in the United States. Washington, D.C.: Joseph Henry Press.

Morgan, Gareth. 1997. Images of organizations. Thousand Oaks, CA: SAGE Publications.

Moynihan, Donald. 2006. What Makes Hierarchical Networks Succeed? Evidence from Hurricane Katrina. Paper presented at the annual meeting of the Association of Public Policy and Management, November 2-4, 2006, Madison, Wisconsin. http://www.lafollette.wisc.edu/appam/moynihankatrina.pdf [accessed on January 17, 2008].

2005. Leveraging Collaborative Networks in Infrequent Emergency Situation. Washington DC: IBM the Center for the Business of Government. http://www.businessofgovernment.com/pdfs/MoynihanReport.pdf [accessed on January 17, 2008].

Nohria, Nitin and Robert G. Eccies, (eds.) 1992. Networks and organizations: Structure, form and action. Boston, MA: Harvard Business School.

Nonaka, Ikujiro. 1994. A dynamic theory of organizational knowledge creation. Organization Science 5 (1): 14-37.

Orlando Sentinel. 2004. Content Analysis of News reports 8/01/04 - 11/30/04.

Orton, J. Douglas and Karl E. Weick. 1990. Loosely coupled systems: A reconceptualization. Academy of Management Review 15(2):203-223.

Ostrom, Einor. 1998. A behavioral approach to the rational choice theory of collective action. American Political Science Review 92 (1): 1-22.

Pellig, Mark. 2003. The Vulnerability of Cities: Natural Disasters and Social Resilience. Earthscan Publications, London.

Powell, Walter W. 1990. Neither market nor hierarchy: Network form of organization. In B. M. Staw and L. L. Cummings, eds. Research in organizational behavior. 12 Greenwich, CT: JAI Press: 295-336.

Provan, Keith G., Mark A. Veazie, L. K. Staten, N. I. Teufel-Shone . 2005. The Use of Network Analysis to Strengthen Community Partnerships Public Administration Review 65(5): 603 - 613.

Rochet, Claude, Oliver Keramidas, and Lugdivine Bout. 2008. Crisis as change strategy in public organizations. Internatiopnal review of Administrative Sciences 74(1): 65-77.

Sabatier, Paul. 1987. Knowledge, policy-oriented learning, and policy change. Knowledge: Creation, Diffusion, Utilization 8 (4): 649-92. 
Scott, Richard W. and Gerald F. Davis. 2007. Organizations and organizing: Rational, natural, and open system perspectives. Upper Saddle River, NJ: Prentice Hall.

Schneider, Saundra K. 1995. Flirting with disaster: Public management in crisis situations. Armonk, NY: M. E. Sharpe.

Seeger, Matthew. W., Timothy L. Sellnow and Robert R. Ulmer (2003). Communication and organizational crisis. Westport, Connecticut: Praeger.

Simon, Herbert A. 1996. The sciences of the artificial. Cambridge, MA: M.I.T. Press.

. 1947. Administrative behavior: A study of decision-making processes in administrative organizations. New York: Macmillan.

Thompson, James D. 2007. Organizations in Action: Social Science Basis of Administrative Theory ( $5^{\text {th }}$ print) New Brunswick, NJ: Transaction Publishers.

Tierney, Kathleen J. 2000. Implementing a seismic computerized alert network (SCAN) for Southern California: Lessons and guidance from the literature on warning response and warning systems. Disaster Research Center, University of Delaware, Newark, DE.

Tierney, Kathleen J., Michael K. Lindell and Ronald W. Perry. 2001. Facing the unexpected: Disaster preparedness and response in the United States, Washington, D.C.: Joseph Henry Press.

Wagenaar, Hendrik. 2007. Governance, Complexity, and Democratic Participation: How Citizens and Public Officials Harness the Complexities of Neighborhood Decline The American Review of Public Administration 37(1): 17-50.

Wang, XiaoHu and Naim Kapucu. 2008. Public complacency under repeated emergency threats: Some empirical evidence, Journal of Public Administration Research and Theory 18(1):57-78.

Wasserman, Stanley and Katherine Faust. 1994. Social network analysis: Methods and applications. Cambridge, Cambridge University Press.

Waugh, William L. Jr. 2000. Living with hazards, dealing with disasters: An introduction to emergency management. Armonk, NY: M.E. Sharpe. . (ed.). 2006. The Political Costs of Failure in the Katrina and Rita Disasters. In W.L. Waugh, Jr. (ed.) 'Shelter from the Storm: Repairing the National Emergency management System after Hurricane Katrina'. The Annals of the American Academy of Political and Social Science. 604 (March). Special Issue. pp. 10-25.

Weaver, T. (2004) 'Proof is in the Pudding: Florida CERT makes a difference in four hurricanes'. The Connection 7(1).

http://www.naem.com/connection/11/fl1.html [accessed on march 18, 2008]. 
Weber, Edward and Anne M. Khademian. 2008. Wicked problems, knowledge challenge, and collaborative capacity builders in network setting. Public Administration Review. 68(2): 334-349.

Weick, Karl E. 2001. Making sense of the organization. Oxford, Massachusetts: Blackwell Business.

. 1995. Sensemaking in organizations. Thousand Oaks, CA: Sage. 1993. The collapse of sensemaking in organizations: The Mann Gulch disaster. Administrative Science Quarterly 38:628-652.

Weick, Karl E. and Karlene H. Roberts. 1993. Collective mind in organizations: Heedful interrelating on flight decks. Administrative Science Quarterly: 357381.

Weick, Karl E. and Kathleen M. Sutcliffe. 2001. Managing the unexpected: Assuring high performance in an age of complexity. San Francisco: Jossey Bass Publishers.

Wildavsky, Aaron. 1971. Searching for Safety. New Brunswick, NJ: Transaction Publishers.

Williams, D.E. and B.A. Olaniran. 1998. Expanding the crisis planning function: Introducing elements of risk communication to crisis communication practice. Public Relations Review 24(3): 387-400.

Wise, Charles. R. 2006. Organizing for homeland security after Katrina: Is adaptive management what's missing? Public Administration Review 66 (3): 302-318. 